\title{
A Bourdieusian Perspective on Acculturation: Mexican Immigrants in the United States
}

\author{
Leonel Prieto *, Tagi Sagafi-nejad and Balaji Janamanchi \\ Division of International Business and Technology Studies, Sanchez School of Business, \\ Texas A\&M International University, 5201 University Boulevard, Laredo, TX 78045, USA; \\ E-Mails: sagafinejad@loyola.edu (T.S.); bjanamanchi@tamiu.edu (B.J.); \\ Tel.: +1-956-206-3351 (T.S.); +1-956-326-2537 (B.J.)
}

* Author to whom correspondence should be addressed; E-Mail: 1prieto@ tamiu.edu; Tel: +1-956-326-2580.

Received: 2 November 2013; in revised form: 2 December 2013 / Accepted: 2 December 2013 / Published: 13 December 2013

\begin{abstract}
This article uses Bourdieu's theory of practice (BTOP) to understand immigrants' acculturation. It synthesizes research findings by discussing acculturation as: (1) equalization of immigrants' and natives' development (convergence); (2) language and social practices related to economic, cultural, social and symbolic capitals; and (3) relationships among acculturation indicators in the evolving interactions among immigrants' habituses and their economic, cultural, social, and symbolic capitals. Hypotheses tests use micro, meso and macro-level practices. Results confirm a systemic correspondence between the habitus and different types of capital, suggesting that relationships among components of immigrants' habituses and their capitals change as acculturation develops.
\end{abstract}

Keywords: Bourdieu's theory of practice; immigration; Mexican immigrants; United States; acculturation practices

\section{Introduction}

Acculturation may be viewed as a process of becoming [1,2], and the challenge of acculturation studies is to further understand differentiated and common becomings. Acculturation is realized 
through practices taking place in multiple contexts, time periods, communication styles, power and other configurations, and forms of knowledge and knowing. These may give raise to the emergence of new subjectivities, types of knowledge, identities, life trajectories, aspirations, hybridities, and novelties [3-5].

The study of acculturation may benefit from different perspectives [6] and/or meta theories that nest or integrate other theories. We find particularly relevant Bourdieu's theory of practice (herein BTOP) [7] because such meta-theory: (1) allows consideration of variability among acculturation domains, individuals, groups, and contexts; and (2) permits us to understand acculturation in terms of objective material, social, and cultural structures as well as constituting practices and experiences of individuals and groups ([8], p. 3).

This article uses BTOP to understand the complex unfolding of acculturation processes through an examination of Mexican immigrants' acculturation in the United States. It discusses acculturation as: (1) equalization of immigrants and natives' development (convergence); (2) language and social practices; and (3) relationships among acculturation indicators reflected in the evolving interactions among immigrants' habituses and their economic, cultural, social, and symbolic capitals.

\section{Theoretical Framework and Hypotheses}

We define BTOP's main constructs drawing from Bourdieu [7]. These constructs include capitals (economic, cultural, social, and symbolic), habitus and field. Economic capital entails ownership of economic and financial assets and is of most concern for immigrants and host societies. It is largely fungible, pervasive, and it has a large exchange rate. Cultural capital derives from life and institutional experiences. It is the most difficult capital to attune to that of natives because, unlike natives, immigrants embody capital from more than one culture. Social capital includes the actual and potential resources of a network of 'institutionalized relationships of mutual accordance and recognition' ([9], p. 65) and can be categorized as 'in-group' or 'institutional.' 'In-group' social capital includes mutually recognized relationships between the immigrant and her family, friends, ethnic, religious or other groups. 'Institutional' social capital comprises formal and informal institutionalized relationships mutually recognized by the immigrant and, perhaps more importantly, her host society. Symbolic capital includes prestige, recognition, social status, or honor. It derives from economic, cultural, and social capitals. The exchange rate of such capitals to symbolic capital is largely granted by the habitus of the dominant players in a given field [7] and or society.

The habitus encompasses immigrants' dispositions, schemes, gender, class, and ethnic identities. As such, it determines immigrants' consumption and production of symbols, and changes in habitus lead to changes in acculturation. Thus, acculturation may be viewed as a set of dynamics between the immigrants' habituses and their total capital vis a vis host society's relevant fields. An immigrant's starting point in a host society (with a given habitus and capital) will set expectations and a desired future life trajectory that correspond, roughly, to her actual and expected total capital, her capital distribution, and her perception of her relevant fields. While most immigrants expect to do well in, and to be loyal to, the host society [10], their good intentions may not be matched by other components of their habituses, their total capital, and host society's relevant fields. Certain habituses and sets of 
capital may lead to perceiving success as either highly likely or unlikely in certain fields. In other words, the individual aims for what she perceives as feasible [7,11].

Field is the social space where agents struggle to better their positions in terms of the capital(s) of interest. Examples include educational, economic, and financial fields. Fields differ in their rules, logic, structure, and in the relative weight given to specific forms of capital. Their dynamics are a function of changes in the habituses, and of economic, cultural, social and symbolic capitals. We assume that fields are partly embodied in the habitus. Likewise, in accordance with BTOP, we consider immigrants' field positioning as deriving from their diverse sets of economic, cultural, social, and symbolic capitals.

BTOP $[7,9,11,12]$ suggests that immigrants acquire the dispositions, expectations, and sensibilities that will help them to respond to their relevant fields as they interact with others on a daily basis. Thus, we may view immigrants as relatively new players with diverse sets of habituses and economic, cultural, social, and symbolic capitals playing in the different fields of the host society aiming to become reasonably "good players".

\subsection{Acculturation as Convergence of Immigrants' and Natives' Development}

Drawing from Sen (1999) [13], we expect successfully acculturated immigrants to obtain equivalent socio-economic outcomes to those of individuals born in the host society. We compare immigrants born in Mexico to U.S. natives in terms of educational level, financial literacy, annual household income, and usage sophistication of financial services. In line with BTOP's tenet, there is a compounding effect of immigrants' starting conditions, host society's specific relevant fields for immigrants, the nature of acculturation trajectories, and immigrants' acculturation success rate [14,15].

Per BTOP, complete acculturation in immigrants will reflect cognitions, expectations, and performance similar to natives. We hypothesize that:

H1: The fewer the differences in development indicators (e.g., educational level, financial literacy, annual household income, financial practices, language, and social practices) between US-born and Mexico-born individuals the higher the degree of immigrants' acculturation.

\subsection{Acculturation as Language and Social Practices}

Below, we discuss acculturation of Mexico's immigrants in terms of language and social practices, according to ARSMA-II scale [16], and relate it to some meso-level development indicators.

An immigrant's acculturation level may positively associate with duration of stay in the host society $[16,17]$ and education $[18,19]$. It may be expected that the longer the duration of stay in the host society the better the immigrant's job and economic situation and hence the higher her income [20,21].

Both higher income [22,23] and better knowledge of the financial field as well as of the overall socio-economic system obtained via a longer duration may positively associate with a more sophisticated use of financial services. Likewise, financial knowledge is an important factor in determining both quality of financial decision making and usage sophistication of financial services [24,25].

Additionally, we anticipate that the higher the educational level of an individual, the greater her wealth [26,27] and her financial literacy [28,29] and the greater her use of sophisticated financial services. Better educated individuals will be more resourceful, in searching for, and using quality 
information, which may be positively related to higher quality investment decision-making [30,31]. Similarly, education is positively related to socio-economic development [32] and it has been considered a crucial component of cultural capital [7,12]. Summing up, we hypothesize that:

$\mathrm{H} 2$ : Acculturation level is positively associated to economic capital, cultural capital, and social capital.

\subsection{Acculturation as Changing Habituses and Capitals}

Following BTOP, we expect that as immigrants acculturate: (1) their cultural, social, symbolic, and economic capitals will increase; and (2) factors constituting acculturation may relate differentially among themselves thereby potentially having different effects at different acculturation stages. Therefore, we hypothesize that:

H3: The habitus and economic, social, cultural and symbolic capitals may relate differentially at different acculturation stages.

\section{Methodology}

\subsection{Sample}

Data were gathered in two waves. In the first one, we use an English version questionnaire, and in the second one, we use: questionnaires in either English or Spanish. Both questionnaires were administered to consumers of financial services in a city in the southwestern United States. The questionnaires were randomly administered in person at financial services providers, of which approximately 70 percent were banks. Financial service providers were selected aiming to obtain a sample with about $50 \%$ immigrants and $50 \%$ natives.

We obtained data from 302 English questionnaires and 299 bilingual questionnaires at 15 locations throughout the city. We disregarded 45 participants born either outside the United States or Mexico as well as 29 respondents with missing birthplace data. Our final sample size was 527. US-born individuals were of Mexican heritage and from different generations.

\subsection{Measures}

We use three operationalizations of acculturation. First, we define acculturation as the degree of convergence between Mexican immigrants in the United States and U.S.-born individuals in educational level, annual household income, financial literacy, and sophistication of usage of financial services. Second, we consider acculturation level in terms of language and social practices as the degree to which the individual thinks, writes letters, watches TV, reads books, socializes, and speaks in either Spanish or English. We operationalize this perspective using the ARSMA-II scale [16] and relate it to economic, cultural, and social capitals. Third, we examine acculturation as the nature of immigrants' habituses and their degree of economic, cultural, social and symbolic capitals. We use the ARSMA-II scale as a proxy of the habitus, and we operationalize the different capital types as indicated below. Using multiple regression analysis we examine relationships among the habitus and the set of the different capitals studied. Outcome variables include each of the key variables studied (e.g., working experience, annual household income, sophistication in usage of financial services, educational level, financial literacy, and acculturation level (herein unless stated otherwise 
acculturation level will refer to that measured by the ARSMA-II scale)), and the remainder were independent variables. These relationships were assessed at three acculturation levels: (1) low level-Mexico-born individuals-; (2) high level—U.S.-born individuals-; and (3) middle level—a random sample of 87 individuals drawn from the set of Mexico-born individuals and 88 individuals drawn from the set of U.S.-born individuals-.

To represent economic capital, we used annual household income and usage sophistication of financial services. Financial services were assessed as either used or not used. A set of 16 financial services was grouped into lower, intermediate, and higher order financial needs, depicting the degree of sophistication of financial services. Inter-rater agreement was 0.85 or higher when independently sorting financial services by level of sophistication. In addition, to further understand economic capital, in terms of financial practices and preferences, we analyzed some of its micro components by making between group comparisons of the following practices: salient factors in selecting a financial institution (we included 22 factors), and financial transaction methods used (we consider seven methods).

Educational level and financial literacy represented cultural capital. Education is positively correlated to proficiency of the host country's language [26] as well as to the ability of the individual to adjust structurally to the host country's system [33].

We assessed 'in-group' social capital by duration of stay and working experience. We expect individuals to have more social interactions, relationships and social contacts the longer their duration in the host society. Similarly, we expect immigrants to be more highly attuned to the relevant fields of the host society, the greater their working experience. Working experience may be crucial in establishing contacts and gathering information for future employment and as "hands on" acquired cultural capital valued by employers [34]. We also discuss, based on the extant literature, but not measured, 'institutional' social capital.

We assessed financial literacy based on answers to four questions about general financial knowledge.

\subsection{Statistical Methods}

We used confirmatory factor analysis to verify the psychometric properties of the acculturation scale. We assessed differences in development equalization, between U.S.- and Mexico-born respondents using Mann-Whitney and t-tests. Both tests yielded similar results, therefore we only provide the Mann-Whitney results. Similarly, we used t-tests and hierarchical regression analyses to test our hypotheses.

\section{Results}

\subsection{Acculturation Scale's Psychometric Properties}

Factor analysis and t-tests confirmed ARSMA-II's two factor structure: the Mexican-oriented scale (MOS) and the Anglo-oriented scale (AOS). All items loaded in the expected factors, and all loadings exceeded the acceptable threshold level (0.4) [35]. The Cronbach's alpha for MOS was 0.88, and that for AOS was 0.80. Both Cronbach's alpha estimates are deemed reliable [35]. 


\subsection{Description of Control Variables}

About $42 \%$ and $43 \%$ of respondents were male and approximately $58 \%$, and $57 \%$ were female, for Mexico- and U.S.-born individuals, respectively. Nearly $1 \%$ and $4 \%$ of respondents were 18 years old or younger, 3\% and 16\% and were between 19 and 24 years old, 22\% and 31\% between 25 and 34 years old, $37 \%$ and $30 \%$ between 35 and 49 years old, $23 \%$ and $15 \%$ between 50 and 64 years old, $8 \%$ and 3\% 65 years or older for Mexico and US born individuals, respectively. Roughly $64 \%$ and 55\% of respondents were married, $21 \%$ and $34 \%$ were single, $10 \%$ and $10 \%$ were divorced, and $5 \%$ and $1 \%$ were widowed for Mexico and US born individuals, respectively. Values for variables constitutive of economic, cultural, and social capitals appear on Table 1.

Table 1. Means and correlation matrix.

\begin{tabular}{|c|c|c|c|c|c|c|c|}
\hline Practices & $\begin{array}{c}\text { Mean } \\
\text { (Standard deviation) }\end{array}$ & 1 & 2 & 3 & 4 & 5 & 6 \\
\hline $\mathrm{H}$ : Acculturation level ${ }^{\mathrm{a}}$ & $\begin{array}{l}2.1(0.80) \\
{[3.2](1.15)}\end{array}$ & & & & & & \\
\hline $\begin{array}{l}\text { EC: Usage } \\
\text { sophistication of } \\
\text { financial services }\end{array}$ & $\begin{array}{c}3.16(1.77) \\
{[3.84](1.63)}\end{array}$ & $\begin{array}{c}-0.12 \\
{[-0.004]}\end{array}$ & & & & & \\
\hline $\begin{array}{l}\text { EC: Annual } \\
\text { household income }^{c}\end{array}$ & $\begin{array}{c}2.2(1.31) \\
{[2.98](1.65)}\end{array}$ & $\begin{array}{l}0.24 * * \\
{[0.13 *]}\end{array}$ & $\begin{array}{c}0.12 \\
{[0.20 * *]}\end{array}$ & & & & \\
\hline CC: Educational level ${ }^{\mathrm{d}}$ & $\begin{array}{c}2.46(1.23) \\
{[3.07](1.17)}\end{array}$ & $\begin{array}{c}0.22 * * \\
{[0.14 * *]}\end{array}$ & $\begin{array}{c}0.22 * * \\
{[0.08]}\end{array}$ & $0.37 * *$ & & & \\
\hline CC: Financial literacy ${ }^{\mathrm{e}}$ & $\begin{array}{c}1.53(1.04) \\
{[1.84](1.08)}\end{array}$ & $\begin{array}{c}0.16 * \\
{[0.13 *]}\end{array}$ & $\begin{array}{c}0.17 * \\
{[0.12 *]}\end{array}$ & $\begin{array}{c}0.10 \\
{[0.27 * *]}\end{array}$ & $\begin{array}{c}0.23 \\
* *[0.26 \\
* *]\end{array}$ & & \\
\hline $\begin{array}{l}\text { SC: Working } \\
\text { experience }^{f}\end{array}$ & $\begin{array}{c}4.45(1.67) \\
{[4.64](1.44)}\end{array}$ & $\begin{array}{l}-0.01 \\
{[0.09]}\end{array}$ & $\begin{array}{l}0.21 * * \\
{[0.12 *]}\end{array}$ & $\begin{array}{c}0.19 * \\
{[0.29 * *]}\end{array}$ & $\begin{array}{c}0.15 \\
*[0.06]\end{array}$ & $\begin{array}{c}0.18 * \\
{[0.18 * *]}\end{array}$ & \\
\hline $\begin{array}{l}\text { SC: Duration of stay } \\
\text { in the US }{ }^{\mathrm{g}}\end{array}$ & $4.12(1.18)$ & 0.06 & 0.03 & 0.09 & -0.11 & 0.02 & $0.25 * *$ \\
\hline \multicolumn{8}{|c|}{$\begin{array}{l}\text { Notes: } \mathrm{N} \text { (US-born) }=326, \mathrm{~N} \text { (Mexico-born) }=181, * p<0.05, * * p<0.01 \text {. t-tests were two-tailed. Means and } \\
\text { correlations for US-born individuals appear in [] parentheses; }{ }^{\mathrm{a}} \mathrm{H}=\text { Habitus, acculturation level was measured on a scale } \\
\text { from } 1 \text { (least) to } 5 \text { (most) acculturated; }{ }^{\mathrm{b}} \mathrm{EC}=\text { Economic Capital, usage sophistication of financial services was measured } \\
\text { on a scale from } 1 \text { (least) to } 5 \text { (most); }{ }^{\mathrm{c}} \text { six categories measured annual household income, thereby, a value of } 3 \\
\text { corresponds, approximately, to } \$ 55,000 \text { whereas a value of } 2.2 \text { roughly corresponds to } \$ 29,000 ;{ }^{\mathrm{d}} \mathrm{CC}=\mathrm{Cultural} \text { Capital, } \\
\text { educational level was measured using five categories. Thus, a value of } 3.1 \text { corresponds to an educational level slightly } \\
\text { above a technical/professional certification level whereas a value of } 2.5 \text { corresponds to a schooling level between high } \\
\text { school and a technical/professional certification level; }{ }^{\mathrm{e}} \mathrm{CC}=\mathrm{Cultural} \text { Capital, financial literacy was measured on a scale } \\
\text { from } 0 \text { to } 4 ;{ }^{\mathrm{f}} \mathrm{SC}=\text { Social Capital, working experience was measured using six categories. Thus, a value of } 4.5 \\
\text { corresponds roughly to } 10.5 \text { years of working experience; and }{ }^{\mathrm{g}} \mathrm{SC}=\text { Social Capital, duration of stay was measured using } \\
\text { six categories. Thus, a value of } 4.12 \text { corresponds approximately to } 16 \text { years. }\end{array}$} \\
\hline
\end{tabular}




\subsection{Hypothesis Testing}

\subsubsection{Acculturation as Convergence: Immigrants Equalizing Natives’ Development}

We hypothesized, and found, that Mexico-born individuals will have lower levels of education, financial literacy, annual household income, and usage sophistication of financial services as well as different social and language practices than those born in the United States (see Table 2). These results support H1.

Regarding micro-level banking and financial services practices, which are partly constitutive of economic capital, U.S.-born respondents seem more demanding and more concerned with convenience and speed of financial services. They gave more importance in selecting a financial institution to ATM availability, speed of services, hours of operation, quality of services and provision of free services whereas Mexico-born respondents preferred financial service providers offering services in multiple languages and cross-country financial transactions.

Table 2. Acculturation development differences among US-born and Mexico-born respondents.

\begin{tabular}{|c|c|c|c|}
\hline Practice & $\begin{array}{c}\text { US-born } \\
\text { respondents }\end{array}$ & $\begin{array}{c}\text { Mexico-born } \\
\text { respondents }\end{array}$ & $\begin{array}{c}\text { Statistical } \\
\text { significance }\end{array}$ \\
\hline H: Acculturation level & $3.2(1.15)$ & $2.1(0.80)$ & $p<0.001$ \\
\hline $\begin{array}{l}\text { EC: Usage sophistication of } \\
\text { financial services }{ }^{\text {a }}\end{array}$ & $3.8(1.63)$ & $3.2(1.77)$ & $p<0.001$ \\
\hline EC: Annual household income ${ }^{b}$ & $3.0(1.64)$ & $2.2(1.31)$ & $p<0.001$ \\
\hline CC: Educational level ${ }^{\mathrm{c}}$ & $3.1(1.17)$ & $2.5(1.24)$ & $p<0.001$ \\
\hline CC: Financial literacy ${ }^{d}$ & $1.8(1.1)$ & $1.5(1.0)$ & $p<0.05$ \\
\hline
\end{tabular}

Notes: $\mathrm{N}($ US-born $)=326, \mathrm{~N}$ (Mexico-born) = 181; standard deviations appear in parentheses; Mann-Whitney tests were two-tailed; ${ }^{\mathrm{a}} \mathrm{EC}=$ Economic Capital, usage sophistication of financial services was measured on a scale from 1 (least) to 5 (most); ${ }^{b}$ EC = Economic Capital, six categories measured annual household income, thereby, a value of 3 corresponds, approximately, to $\$ 55,000$ whereas a value of 2.2 roughly corresponds to $\$ 29,000 ;{ }^{c} \mathrm{CC}=$ Cultural Capital, educational level was measured using five categories. Thus, a value of 3.1 corresponds to an educational level slightly above a technical/professional certification level whereas a value of 2.5 corresponds to a schooling level between high school and a technical/professional certification level; ${ }^{\mathrm{d}} \mathrm{CC}=$ Cultural Capital, financial literacy was measured on a scale from 0 to 4; and SC = Social Capital, working experience was measured using six categories. Thus, a value of 4.5 corresponds, roughly, to 10.5 years of working experience.

Additionally, U.S.-born individuals used more: investment services, personal loans, online financial services, credit cards, home equity loans, telephone with a live representative, telephone with an automated phone system, online financial services, and less debit cards and snail mail than Mexico-born individuals. (Due to space limitations we did not include data on these micro practices constitutive of economic capital. The authors will gladly provide such data upon request.).

As usage sophistication of financial services increases, factors constituting cultural and economic capitals become more important than demographic factors. Whereas gender and age are associated to usage sophistication of financial services at low levels of acculturation financial literacy, education, and annual household income are positively associated to higher acculturation levels. The results of the 
12 practices constituting the ARSMA-II scale, give support, at the micro-level, to earlier results indicating a higher level of cultural, economic, social, symbolic, and total capital for U.S.-born individuals than for Mexico-born individuals. These alternative acculturation micro practices support the first hypothesis that the fewer the differences in selected development indicators between US-born and Mexico-born individuals the higher the degree of immigrants' acculturation.

\subsubsection{Acculturation as Language and Social Practices}

For Mexico-born immigrants, gender, age, marital status, and working experience did not affect acculturation level, while annual household income and educational level were positively associated to acculturation level. Contrary to our expectations, duration of stay in the United States was not associated to acculturation level (see Table 3). This result may derive from the relatively long duration, on average more than 16 years, of Mexico-born respondents as well as from the range restriction of this factor.

Item analyses of the ARSMA-II scale indicate, as expected, that Mexico-born individuals' social and language practices are more often in Spanish whereas U.S.-born individuals' practices are more often in English. However, both U.S.- and Mexico-born individuals equally enjoy speaking Spanish.

Table 3. Relationships between acculturation level and indicators of economic, cultural, and social capitals for Mexico-born respondents.

\begin{tabular}{ccc}
\hline Dependent variable & Independent variable's Beta coefficient & $\mathbf{R}^{\mathbf{2}}$ \\
\hline Acculturation level & 0.24 Annual household income $* * *$ & 0.06 \\
Acculturation level & -0.11 Usage sophistication of financial services & 0.012 \\
Acculturation level & 0.06 Duration of stay in the US & 0.004 \\
Acculturation level & -0.003 Working experience & 0.001 \\
Acculturation level & 0.22 Educational level $* *$ & 0.05 \\
Acculturation level & 0.16 Financial literacy * & 0.03 \\
\hline
\end{tabular}

Notes: Acculturation level according to ARSMA-II scale (see [18]); $\mathrm{N}=181$. Thus, only Mexico-born individuals are considered here; $* p<0.05, * * p<0.01$, and $* * * p<0.001$; annual household income and usage sophistication of financial services were used as proxies of economic capital; duration of stay in the US and working experience were used as proxies of social capital; and educational level and financial literacy were used as proxies of cultural capital.

Cultural capital's components, that is, financial literacy and educational level, were positively associated to acculturation level. Annual household income was positively associated to acculturation level while usage sophistication of financial services was not.

Concerning economic capital, as indicated by micro-level banking and financial services practices, less acculturated individuals give more importance to cross-country and multiple languages financial services than financial convenience services (online access, speed of services, and proximity to home/workplace). They also give less importance to financial services' quality and use less frequently online financial services and telephone with a live representative as transacting financial methods. Usage sophistication of financial services was associated with demographic factors, working experience, and financial literacy. Older, unmarried, male individuals and individuals with more working experience, education and financial literacy tend to be more sophisticated in using financial 
services. Usage sophistication of financial services was not associated to acculturation level neither was duration of stay in the United States. Single individuals with more working experience had a higher financial literacy. Likewise, educational level was positively related to annual household income.

The results from conceiving acculturation as language, social, banking and financial practices undertaken by Mexico-born respondents confirm that: (1) less acculturated individuals carry out more social and language practices in Spanish; (2) acculturation is positively associated to annual household income and educational level; and (3) single, older individuals with more working experience, education, and financial literacy are more sophisticated in using financial services regardless of their acculturation level.

For Mexican-born individuals: (1) acculturation level is positively associated to annual household income, educational level, and financial literacy; and (2) indicators of social capital, that is, duration of stay and working experience, did not directly relate to acculturation level neither did sophistication usage of financial services. We indicated that a better operationalization of social capital indicators and a sample with less range restriction may provide support for the posed positive relationship between social capital and acculturation. Nonetheless, as discussed earlier, in considering acculturation as convergence of immigrants' development with that of natives, acculturation level is positively related to economic, cultural, and social capitals. Thus, $\mathrm{H} 2$ is, by and large, supported.

\subsubsection{Acculturation as Changing Habituses and Capitals}

Different factors either within and/or between the habitus and the four types of capital, produce the highest positive returns at different acculturation stages. Results from the set of relationships among acculturation indicators shown in Table 4 indicate that cultural capital, as measured by educational level and financial literacy, has the highest number of significant regression coefficients. Acculturation is significantly predicted by four, two, and one, out of five, independent variables, for Mexico-born individuals, Mexico-born (50\% of sample) plus US-born individuals (50\% of sample) and US-born individuals, respectively. As acculturation level increases cultural capital (e.g., education) and economic capital (e.g., income) remain key explanatory factors. We discussed earlier that demographic factors are correlated to micro components of economic capital such as sophistication in the use of financial services. Likewise, we discussed above that salient factors in selecting a financial institution, financial services used, and financial transaction methods utilized are different for individuals with different acculturation levels. Similarly, we indicated that higher acculturation levels are associated with higher financial literacy, education, and annual household income. These results suggest that different factors either within and or between the habitus and the four types of capital, may have differential effects at different acculturation stages (e.g., as acculturation increases factors with explanatory power change from demographic factors to cultural capital and, thereafter, to economic capital which, in turn, may be limited by cultural capital). This suggests that different factors and different combinations of them may be needed to more appropriately "identify" acculturation at different stages). This supports H3.

The diverse set of development banking and financial service practices, encompassing both meso and micro levels as well as a set of language and social practices discussed above shows that the set of relationships among some of the factors constituting acculturation may change over time. 
Table 4. Multiple regression results relating the habitus to social, economic, and cultural capitals.

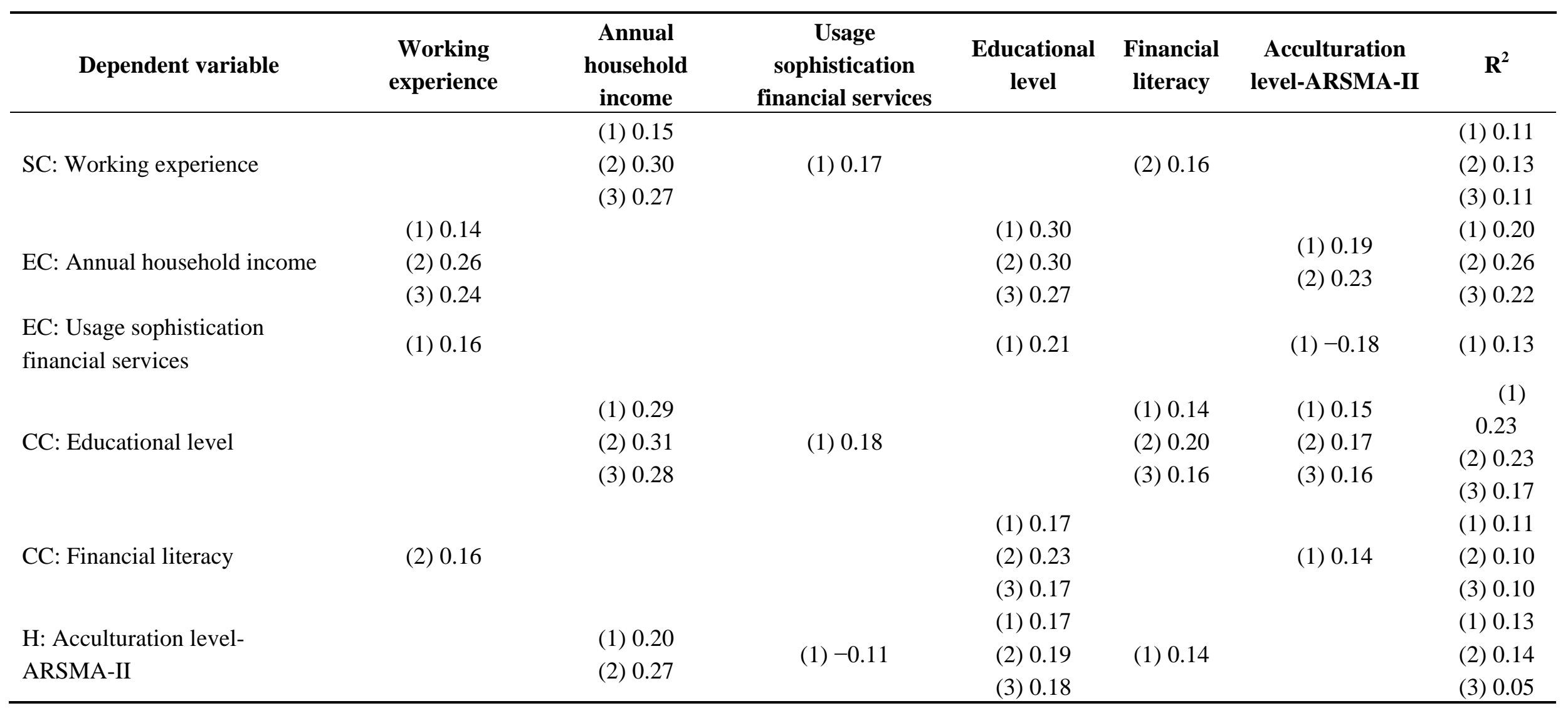

Notes: (1) Only significant Beta coefficients at $p<0.05$ or lower are shown; (2) Samples sizes were 181, 182, and 182 for Mexico, Mexico+US, and US, respectively; and (3) Parentheses (1), (2), and (3) denote results for Mexico, Mexico+US, and US, respectively; (4) CC = Cultural Capital; EC = Economic Capital; $\mathrm{H}=\mathrm{Habitus;}$ and $\mathrm{SC}=$ Social Capital. 


\section{Discussion}

Results of the hypothesis tests suggest that less acculturated individuals have habituses less attuned to the host society and less economic, cultural, social, symbolic and total capital. Our data only partially support the expected positive association between social capital and acculturation. This result may be due to the data's range restriction and/or how social capital is operationalized. Future research should examine social capital in terms of resources derived from family, friends, and acquaintances. Below, attempting to further understand the dynamics of immigrants' habituses and capitals, we discuss acculturation by looking at some interplays between immigrants' habituses and their cultural, economic, social, and symbolic capitals relating them to host society's relevant fields.

Compared to natives, Mexican immigrants have less attuned habituses, and fewer resources and opportunities to successfully decipher, or interpret, 'the code' of the host society's socio-economic system. This will cause them to use more interpretation attempts and substantially more capital than natives in attempting to decipher and use such 'code', which may lead to feelings of lacking a sense of order and continuity in their life experiences [36]. Mexican immigants may frequently reflect about their situation and their identities [37], which may negatively impact their habituses [5,38], particularly, in hostile environments [39-41].

Immigrants, by having less total capital, and less attuned habituses have to deal with relatively low quality dialogues with the Other $[42,43]$ since dialogue qua dialogue entails considering the Other as equal [44]. Attempts to decipher the "code" of the host society, the effects of some everyday experiences on ontological insecurity, and the potential difficulties in dialoguing with the Other are likely to be worse for immigrant women than for immigrant men given that social relationships are genderized both in the Mexican society and in the US society. Thus, immigrant women are likely to start, and continue, their life trajectories in the host society with less total capital and with more constraints than immigrant men. At the same time, immigrants' dialogues both with the Other and with themselves may create new hybrid cultural spaces [1] as well as opportunities for further attunement of the habitus and accumulation of total capital. These hybridities, some of which may include everyday sensemaking and creative maneuvering [45], reflect diverse degrees of immigrants' realized acculturation and cultural (mis)appropriations.

More acculturated individuals (particularly natives) will have a habitus that is better attuned to the educational system's expectations, since the educational field is by and large a function of the expectations and values of those groups of society that are economically better endowed [7]. They also will have more capital to access, and succeed in, the educational system than less acculturated individuals [12]. Considering that cultural capital gained as education, outside the host society may have a lower exchange rate than that obtained locally [34], Mexico-born immigrants that received their formal education in Mexico may be at a disadvantage vis a vis similarly educated natives. Nonetheless, our results, in agreement with the extant literature [32,46], indicate that education is the factor that relates most to development, and thereby to acculturation. Our results (see Table 1) indicate that cultural capital is involved in six out of nine positive correlations.

Similarly, natives' higher financial literacy may relate to their higher educational attainment, and to their superior knowledge of the financial field. In our study, financial literacy is predicted by social capital, other components of cultural capital (e.g., educational level), and economic capital. In this 
regard, Albareto and Mistrulli [47] suggest that a more attuned habitus to the host society may result in increased and cheaper financial services for immigrants, thereby potentially increasing their economic capital. Generally, immigrants with higher cultural capital may have more power to exercise choice, to appropriate selected cultural components of the host society and to successfully integrate into such society rather than being either assimilated or marginalized. For example, Portes, Escobar and Arana [46] found that better-educated and higher-status immigrants are both more politically involved in the United States and more likely to exercise biculturalism. On the other hand, for many immigrants it is difficult to break the path dependence that characterizes their low total capital and their capitals' distribution.

Mexican immigrants' lower annual household income and lower usage sophistication of financial services may partly relate to social and cultural factors, such as English proficiency, accent, formal and informal institutional knowledge, social networks, and cultural nuances unaccounted for in our operationalization of economic capital and in its interactions with the habitus and other forms of capital. The main difference between US-born and Mexico-born individuals pertains to economic capital, which tends to change more rapidly in acculturation processes than other types of capital [48]. However, as suggested earlier, lack of cultural capital may constrain immigrants' accumulation of their desired capital distribution and total capital.

'In-group' social capital is a key factor in facilitating immigration through social networks of friends and family [10,49], and in increasing (or decreasing) economic and cultural capitals and the "grounding" of the habitus [7,50]. The 'in-group' social capital in our sample may have been relatively high due to the bilingual and bicultural nature of the context from where such sample was drawn. Deficits in "institutional" social capital, see below, may be partially compensated by "in-group" social capital.

Mexico's immigrants' institutional social capital is low since it manifests itself as racism, discrimination, an increasingly difficult regulatory framework, negative labeling, and stereotyping [51,52]. Negative components of 'institutional' social capital [53,54], may cause different types of capital, and their conversion to symbolic capital, to be undervalued. In this regard, immigrants' skills may be under-appreciated and under-estimated [55]. For instance, the labor quality, skills, and creativity exercised in a variety of jobs is generally under-rated and under-appreciated [56]. Similarly, as mentioned earlier, immigrants' education acquired in the country of origin may have a lower exchange rate than that obtained locally [34]. Similar undervaluation is present in the dominant image of the Mexican in the host society's habitus (e.g., as reflected in several forms of host society's narrative [12]). Negative symbolic capital by being subtle, and at times, invisible, imperceptible, and embodied in immigrants' habitus, may constitute the biggest obstacle to immigrants' acculturation. Undervaluation of symbolic capital is bound to be higher for immigrant women than for immigrant men given the masculine domination present in the social relationships that generate economic, cultural, social, and symbolic capitals [57].

Our results indicate that significant relationships between acculturation and its constituting capitals change as acculturation increases. Methodologically, acculturation's definition and its operationalization may partly determine whether or not relationships studied are significant. Similarly, different measures of acculturation may be needed to "properly" assess it at different stages. These findings concur with: (1) acculturation becoming relatively less important as individuals acculturate; and (2) the variability and codependency among immigrants' habituses and their capitals referred earlier. 


\section{Concluding Remarks}

We hypothesized acculturation as convergence of immigrants' and natives' development, as language and social practices related to economic, cultural, social and symbolic capitals, and as changing relationships among immigrants' habituses and their economic, cultural, social, and symbolic capitals.

Since we conceptualize acculturation as a sequential transformation of habituses and capitals, then individuals with less attuned habituses, less total capital, and a less appropriate distribution of capitals will have lower positive returns in their acculturating experiences, and their trajectories will be longer and more difficult than those better positioned.

Our results confirm, under BTOP, the expected systemic correspondence among the habitus and economic, cultural, social, and symbolic capitals. We explored single and composed practices, at micro and meso levels, only briefly referring fields' related macro-institutional dynamics. Likewise, we have shown that the relationships among components of immigrants' habituses and their capitals may change as acculturation develops. A unique universal view of acculturation is not possible, although, BTOP may provide an encompassing framework for considering acculturation while allowing for variability both within and between the habitus and the different forms of capital. Thus, acculturation may be viewed as sets of the thinking, actions, and outcomes taking place in an asymmetrical dialogical space, highlighting how we relate between various players in which the immigrant may be conceived as just one, usually weak, player, not infrequently unaware of the rules of the games being played or without having the power to change, in her favor, the nature of such games.

\section{Acknowledgments}

Research underlying this paper was supported by a grant from the US Department of Education (Title VI. b-P153A060042), supplemented by financial support from BBVA-Compass Bank and Wells Fargo Bank.

\section{Conflicts of Interest}

The authors declare no conflict of interest.

\section{References}

1. Berry, J.W. Immigration, acculturation, and adaptation. Appl. Psychol. 1997, 46, 5-34.

2. Martin, J.S.; Novicevic, M. Social entrepreneurship among Kenyan farmers: A case example of acculturation challenges and program successes. Int. J. Intercult. Relations 2010, 34, 482-492.

3. Aycicegi-Dinn, A.; Caldwell-Harris, C.L. Individualism-collectivism among Americans, Turks, and Turkish immigrants to the US. Int. J. Intercult. Relations 2011, 35, 9-16.

4. Castles, S. Understanding global migration: A social transformation perspective. J. Ethn. Migr. Stud. 2010, 36, 1565-1586.

5. Padilla, A.M.; Perez, W. Acculturation, social identity, and social cognition: A new perspective. Hispanic J. Behav. Sci. 2003, 25, 35-55.

6. Van de Ven, A.H.; Poole, M.S. Alternative approaches for studying organizational change. Organ. Stud. 2005, 26, 1377-1404. 
7. Bourdieu, P. The Logic of Practice; Stanford University Press: Stanford, CA, USA, 1990.

8. Postone, M.; Lipuma, E.; Calhoun, C. Introduction: Bourdieu and Social Theory. In Bourdieu: Critical Perspectives, Calhou, C., Lipuma, E., Postone, M., Eds.; The University of Chicago Press: Chicago, IL, USA, 1993; pp. 1-13.

9. Bourdieu, P.; Wacquant, L. An Invitation to Reflexive Sociology; The University of Chicago Press: Chicago, IL, USA, 1992.

10. Portes, A.; Rumbaut, R.G. Legacies: The Story of the Immigrant Second Generation; University of California Press: Berkeley and Los Angeles, CA, USA, 2001.

11. Bourdieu, P. Outline of a Theory of Practice, Nice, R., Trans.; Cambridge University Press: Cambridge, UK, 1997.

12. Bourdieu, P. Distinction, Nice, R., Trans.; Harvard University Press: Cambridge, MA, USA, 1984.

13. Sen, A. Development as Freedom; Oxford University Press: Oxford, UK, 1999.

14. Berry, J.W. Globalization and acculturation. Int. J. Intercult. Relations 2008, 32, 328-336.

15. Wong-Rieger, D.; Quintana, D. Comparative acculturation of Southeast Asian and Hispanic immigrants and sojourners. J. Cross-Cult. Psychol. 1987, 18, 345-362.

16. Cuellar, I.; Arnold, B.; Maldonado, R. Acculturation rating scale for Mexican Americans II: A revision of the original ARSMA-II scale. Hispanic J. Behav. Sci. 1995, 17, 275-304.

17. Neto, F. Re-acculturation attitudes among adolescents from returned Portuguese immigrant families. Int. J. Intercult. Relations 2010, 34, 221-232.

18. Colon, Y.; Sanchez, B. Explaining the gender disparity in Latino youth's education: Acculturation and economic value of education. Urban. Educ. 2010, 45, 252-273.

19. Lum, T.Y.; Vanderaa, J.P. Health disparities among immigrant and non-immigrant elders: The association of acculturation and education. J. Immigr. Minor. Health 2010, 12, 743-753.

20. Song, S. Finding one's place: Shifting ethnic identities of recent immigrant children from China, Haiti and Mexico in the United States. Ethn. Racial Stud. 2010, 33, 1006-1031.

21. Amuedo-Dorantes, C.; Bansak, C.; Pozo, S. On the Remitting Patterns of Immigrants: Evidence from Mexican Survey Data. Available online: http://www.frbatlanta.org/news/CONFEREN/ payments04/Amuedo-Dorantes.pdf (accessed on 23 November 2010).

22. Demirguc-Kunt, A.; Levine, R. Finance and inequality: Theory and evidence. Ann. Rev. Financ. Econ. 2009, 1, 287-318.

23. Parker, J.A.; Preston, B. Precautionary saving and consumption fluctuations. Am. Econ. Rev. 2005, 95, 1119-1143.

24. Scott, J.M.; Irwin, D. Discouraged advisees? The influence of gender, ethnicity, and education in the use of advice and finance by UK SMEs. Environ. Plan. C 2009, 27, 230-245.

25. Takii, K.; Tanaka, R. Does the diversity of human capital increase GDP? A comparison of education systems. J. Public Econ. 2009, 93, 998-1007.

26. Babones, S. Income, education, and class gradients in health in global perspective. Health Sociol. Rev. 2010, 19, 130-143.

27. Rodriguez-Pose, A.; Tselios, V. Inequalities in income and educational and regional economic growth in Western Europe. Ann. Reg. Sci. 2010, 44, 349-375. 
28. Walstad, W.B.; Rebeck, K.; MacDonald, R.A. The effects of financial education on the financial knowledge of high school students. J. Consum. Aff. 2010, 44, 336-357.

29. Hall, S.; Appleyard, L. City of London, City of earning? Placing business education within the geographies of finance. J. Econ. Geogr. 2009, 9, 597-617.

30. Wang, A. Interplays of investors' financial knowledge and risk taking. J. Behav. Financ. 2009, 10, 204-213.

31. Norvilitis, J.M.; Merwin, M.M.; Osberg, T.M.; Roehling, P.B.; Young, P.; Kamas, M.M. Personality factors, money attitudes, financial knowledge, and credit-card debt in college students. J. Appl. Soc. Psychol. 2006, 36, 1395-1413.

32. Lutz, W.; Sanderson, W.C.; Scherbov, S. The End of Population Growth in the 21st Century: New Challenges for Human Capital Formation and Sustainable Development; Earthscan: London, UK, 2004.

33. Xie, Y.; Greenman, E. Segmented Assimilation Theory: A Reformulation and Empirical Test. Available online: http://personal.psc.isr.umich.edu/yuxie-web/files/working-papers/assim_PAA.pdf (accessed on 8 October 2010).

34. Kanas, A.; van Tubergen, F.; van der Lippe, T. Immigrant self-employment: Testing hypotheses about the role of origin- and host-country human capital and bonding and bridging social capital. Work Occup. 2009, 36, 181-208.

35. Nunnally, J.C.; Bernstein, I.H. Psychometric Theory; McGraw Hill: New York, NY, USA, 1994.

36. Giddens, A. Modernity and Self-identity: Self and Society in the Late Modern Age; Stanford University Press: Stanford, CA, USA, 1991.

37. Paloma, V.; Garcia-Ramirez, M.; de la Mata, M. Acculturative integration, self- and citizenship construction: The experience of Amal-Andaluza, a grassroots organization of Moroccan women in Andalusia. Int. J. Intercult. Relations 2010, 34, 101-113.

38. Lueck, K.; Wilson, M. Acculturative stress in Asian immigrants: The impact of social and linguistic factors. Int. J. Intercult. Relations 2010, 34, 47-57.

39. Berry, J.W.; Sabatier, C. Acculturation, discrimination, and adaptation among second generation immigrant youth in Montreal and Paris. Int. J. Intercult. Relations 2010, 34, 191-207.

40. Mena, F.J.; Padilla, A.M.; Maldonado, M. Acculturative stress and specific coping strategies among immigrant and later generation college students. Hispanic J. Behav. Sci. 1987, 9, 207-225.

41. O’Connell Davidson, J. Troubling freedom: Migration, debt, and modern slavery. Migr. Stud. 2013, 1, 176-195.

42. Collie, P.; Kindon, S.; Liu, J.; Podsiadlowski, A. Mindful identity negotiations: The acculturation of young Assyrian women in New Zealand. Int. J. Intercult. Relations 2010, 34, 208-220.

43. Samochowiec, J.; Florack, A. Intercultural contact under uncertainty: The impact of predictability and anxiety on the willingness to interact with another member from an unknown cultural group. Int. J. Intercult. Relations 2010, 34, 507-515.

44. Levinas, E. Totality and Infinity: An Essay on Exteriority, Lingis, A., Trans.; Duquesque University Press: Pittsburg, PA, USA, 1969.

45. De Certeau, M. The Practice of Everyday Life; University of California Press: Berkeley, CA, USA, 1984. 
46. Portes, A.; Escobar, C.; Arana, R. Divided or convergent royalties? The political incorporation process of Latin American immigrants in the United States. Int. J. Comp. Sociol. 2009, 50, 103-136.

47. Albareto, G.; Mistrulli, P.E. Bridging the Gap between Migrants and the Financial System. Available online: http://www.bancaditalia.it/pubblicazioni/econo/temidi/td11/td794_11/en_td_794_ 11/en_tema_794.pdf (accessed on 23 March 2011).

48. Navas, M.; Rojas, A.J.; Garcia, M.; Pumares, P. Acculturation strategies and attitudes according to the relative acculturation extended model (RAEM): The perspectives of natives versus immigrants. Int. J. Intercult. Relations 2007, 31, 67-86.

49. Haug, S. Migration networks and migration decision-making. J. Ethn. Migr. Stud. 2008, 34, 585-605.

50. Brüß, J. Proud but isolated? Effects of in-group favoritism and acculturation preferences on inter-ethnic attitudes and contact between German, Turkish and resettler adolescents. J. Ethn. Migr. Stud. 2005, 31, 3-27.

51. Adamson, F.B.; Triadafilopoulos, T.; Zolberg, A.R. The limits of the liberal state: Migration, identity and belonging in Europe. J. Ethn. Migr. Stud. 2011, 37, 843-859.

52. Arbona, C.; Olvera, N.; Rodriguez, N.; Hagan, J.; Linares, A.; Wiesner, M. Acculturative stress among documented and undocumented Latino immigrants in the United States. Hispanic J. Behav. Sci. 2010, 32, 362-384.

53. Flores, E.; Tschann, J.M.; Dimas, J.M.; Bachen, E.A.; Pasch, L.A.; de Groat, C.L. Perceived discrimination, perceived stress, and mental and physical health among Mexican-origin adults. Hispanic J. Behav. Sci. 2008, 30, 401-424.

54. Padilla, A. Acculturation and Stress among Immigrants and Later Generation Individuals. In The Quality of Urban Life: Social, Psychological and Physical Conditions, Frick, D., Ed.; Walter de Gruyter: Berlin, Germany, 1987; pp. 101-120.

55. Favell, A. The new face of East-West migration in Europe. J. Ethn. Migr. Stud. 2008, 34, 701-716.

56. Lee, T.L.; Fiske, S.T. Not an outgroup, not yet an ingroup: Immigrants in the stereotype content model. Int. J. Intercult. Relations 2006, 30, 751-768.

57. Bourdieu, P. Masculine Domination, Nice, R., Trans.; Stanford University Press: Stanford, CA, USA, 2001.

(C) 2013 by the authors; licensee MDPI, Basel, Switzerland. This article is an open-access article distributed under the terms and conditions of the Creative Commons Attribution license (http://creativecommons.org/licenses/by/3.0/). 